\section{Concept of innovation in low-income market}

\author{
Vitor Koki da Costa Nogami \\ Universidade Estadual de Maringá, Department of \\ Managerial Science, Maringá-PR, Brazil
}

Francisco Giovanni David Vieira

Universidade Estadual de Maringá, Department of Managerial

Science, Graduate Program of Management, Maringá-PR, Brazil

\section{Andres Rodriguez Veloso}

Universidade de São Paulo, School of Economics, Business and Accounting, Graduate Program in Administration,

Department of Business Management, São Paulo-SP, Brazil

\begin{abstract}
Purpose - Investigate the concept and the adoption of innovation in the low-income market.

Design/methodology/approach - Four different studies were conducted. First, a Delphi study with 126 Marketing and Innovation professors from graduate programs. Second, interviews with 13 professionals, technical assistance professionals and retail managers. Third, two focus groups with low-income consumers. Fourth, survey with 390 respondents.
\end{abstract}

Findings - The results indicate that innovations in the low-income markets are mainly characterized by adaptations and adjustments in products, with emphasis on incremental innovations, not radical. In addition, the adoption of innovation in this context is characterized as late, not initial.

Originality/value - In terms of theoretical contributions, the present study reveals how the concept of innovation is built in the low-income market. From a perspective collectively constructed with information from different market agents (industry, retail and consumers), research findings become robust to understanding a phenomenon. Moreover, in addition to different market agents, different methods of data collection and analysis were also used, further enriching the results. This collective contribution, based theoretically on a literature of social construction, interviewing different market agents and using different methodological approaches, synergistically potentiated the development of this paper.

Keywords - Low-income market; incremental innovation; bottom of the pyramid; innovation adoption; home appliances
Received on

09/09/2016

Approved on

$10 / 20 / 2017$

Responsible editor:

Prof. Dr. Guilherme Shiraishi

Evaluation process:

Double Blind Review

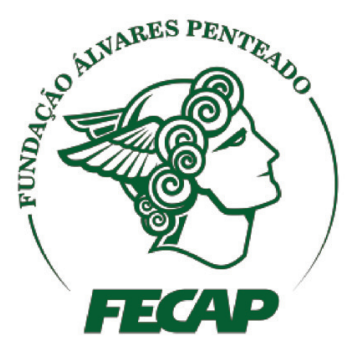

Review of Business Management

DOI: $10.7819 /$ rbgn.v20i1.3044 


\section{Introduction}

The concept of innovation is conventionally associated with technology, modernity, electronics and high-tech products (Kuczmarski, 2003; Prahalad, 2012). Consequently, the idea of high production and development costs is frequently associated with this concept, thus reflecting higher prices to the consumer. However, investigating and practicing innovation go beyond the activities in laboratories spread across universities, large companies and technology centers (Burns \& Stalker 2000; Nogami \& Veloso, 2017).

In other words, studying innovation beyond technological perspectives is a task for the marketing and innovation area (Viswanathan \& Sridharan, 2012). This paper investigates this concept also from a socially constructed perspective, considering the risks and uncertainties that surround the decision-making process of lowincome consumers living in a poor environment lacking basic infrastructure for day-to-day life (Kuczmarski, 2003; Prajogo \& Ahmed, 2006; Rogers, 2003). For this study, we focused on the Brazilian low-income market, comprised of consumers that do not have high purchasing power to take advantage of products and services involving high technology standards. Thus the aim of this paper is: to discover what is the concept of innovation built in the low-income market; consequently, we conducted a multi-method study in order to uncover how the low-income market understands and adopts innovation.

Despite the low purchasing power of low-income consumers, their participation in the consumption of goods and services has increased in Brazil due to several factors, namely: access to information and education, increased income, public initiatives such as social welfare programs and specific tax reductions for the industry, strengthening of the emerging market in the global scenario, and especially access to credit (Barki \& Parente, 2010; Hamilton, 2009; London, 2016; Prahalad, 2005). Within this potential market context, companies have been increasingly seeking to develop products and services for this market segment, especially those involving the concept of innovation (Anderson \& Markides, 2007; Corsi \& Di Minin, 2014; Hang, Chen, \& Subramian 2010; Viswanathan \& Sridharan, 2012).

In contrast to macro level approaches (economic, government, global) or midlevel approaches (market, business strategy, institutional context), our approach begins at the micro level (consumer, individual, user). Once understood what happens at the micro level, it is possible to develop business strategies for the midlevel, and also broad guidelines for the macro level (Viswanathan, 2011).

Previous studies about innovation and low-income markets (also known as bottom of the pyramid - BOP) have focused on product development and business management. This approach has resulted in prescriptive papers on multinational companies' management, both in developed and developing economies. Scant attention has been given to understand the adoption of innovations by BOP consumers (microlevel). This is what we call bottom-up approach rather than top-down approach, in other words, we focus on individual market reality to generate insight to create impactful solutions (Viswanathan, 2016).

Understanding the adoption of innovations by BOP customers can generate information needed by several institutions seeking to disseminate products, services and ideas that could have a positive impact on this market segment. Understanding how the low-income market understands innovation is an initial step to propose solutions for this segment (Viswanathan \& Rosa, 2010). Therefore, the theoretical gap we intend to fill consists of a contribution of the study to advance the theory of innovation in the low-income market, initially focusing more on the consumer than on marketing management. The contribution consists of the better understanding of the market and consumer's lifestyle, to overcome environmental constraints and to provide 
well-being, and to insert innovation elements in this market context (Viswanathan, Sridharan, Gau, \& Ritchie, 2009). Therefore, our analysis focuses on the consumer and all the elements of the environment that shape the market (Medeiros, Vieira, \& Nogami, 2014).

In addition, this study academically contributes in other domains. Firstly, the use of a multi-method study involving a research with different approaches and different market agents brings a fresh perspective to the subject, which is not common. This allowed us to more fully understand how innovation is formatted in the low-income market. Secondly, we advance the innovation theory by studying innovation in the low-income market. The term 'innovation' is commonly associated with advancement, technology and modernity. However, these elements are not directly found in the concept of innovation for the low-income market (Brem \& Ivens, 2013; Brem \& Wolfram, 2014; Corsi \& Di Minin, 2014; Hall, Matos, \& Martin, 2014; Nogami, Vieira, \& Medeiros, 2015b). Therefore, the study of innovation in the low-income market context allowed the advancement of knowledge in this field. To achieve the above objective, the empirical object chosen for the study was the Brazilian home appliance market.

The literature review that supports our research is divided into three parts. First, From Technological to Social Concept of Innovation. Second, From Radical to Incremental Concept of Innovation. Third, Low-Income Market in Brazil. This research was divided into four studies involving different methods. First, a Delphi survey was carried out with 126 professors of Marketing and Innovation. Second, we conducted 13 indepth interviews with home appliance industry and retail professionals. Third, we conducted 2 focus group with low-income consumers. Forth, we conducted a survey with 390 low-income consumers, ending the data collection effort. The first three studies focused on investigating how the low-income market understands the concept of innovation, so we investigated this concept with professors, industry and retail professionals, and consumers. Once the focus is the innovation in the low-income market, it is necessary to collect data from these different actors, not only from the consumers. The fourth study aimed to search specifically the phenomenon of the adoption of innovation by low-income consumers.

\section{From technological to social concept of innovation}

From the point of view of technology, S\&T (Science and Technology) tend to disregard the social, political and cultural scenario, supporting more linear development in search of universal and inexorable truths (Dagnino, 2008). Innovations are differentiated only between more advanced technology (cutting edge, latest, high tech) and less advanced (obsolete, inefficient, outdated). It does not cease to be an evolutionary concept ("Technological Darwinism"), since only the most suitable, efficient and productive technologies survive, and the others are abandoned and forgotten by the market and science (Dagnino, 2008).

Technological determinism is supported in the design of technologies that have autonomous functional logic, which can be performed without reference to society. Technology is understood as social only because of the purpose it serves. According to the deterministic approach, the fate of society depends on a non-social factor (technology), which influences it with no reciprocal influence. That is, progress would be an external influence that falls on society, rather than an expression of values and socio-cultural changes of itself (Anderson \& Billou, 2007).

For this perspective, the relationship between technology and the social environment is unidirectional: while social changes are the result of the technological development, the latter would follow an autonomous process, in accordance with its own principles and interests, as if technology was developed separately from the social context, as a type of extrinsic factor that has its own dynamics (Christensen, 1997; 
Kuczmarski, 2003). In other words, society depends on technology, but technology does not depend on society. Therefore, for an innovation to be considered as such, it must have something literally new, which has not been yet discovered, performed or previously used by anyone, anywhere.

On the other hand, the concept of innovation analyzed by a socially constructed approach considers the social, cultural, historical and human context in which innovation occurs. In this approach, it is necessary to incorporate a relationship with other areas of knowledge, moving towards multi and interdisciplinarity (Viswanathan \& Sridharan, 2012). Innovation in its broadest sense underpins both the technological and social aspects. In the same sense, to understand the meaning of innovation, economic factors and the macroeconomic environment involve the development of a concept of innovation. Going further, in relation to technologically, economically and financially advanced countries, it is possible to notice the innovative capacity of an organization not only by an economic bias, of investing technology, research and development, but also through a social, cultural, human and political approach, to broaden and deepen productivity, socially taking advantage of the material and non-material resources available (Viswanathan \& Sridharan, 2012).

Focused on the social context, this approach argues that for something to be innovative, it must take the meaning of novelty into account, that is, what is the meaning of innovation, the degree of intensity in the innovation, and especially, who regards it as innovation (Prahalad, 2012; Viswanathan \& Sridharan, 2012). In other words, rather than setting limits to what is really new technologically speaking, this approach is concerned with the social benefits that an innovation may cause, even though it may not be such a radical innovation (Antioco \& Kleijnen, 2010; Lee \& Na, 1994; Varadarajan, 2009). It is noteworthy that the two approaches should not be considered as competitors or opposed to one another, but rather as complementary.

\section{From radical to incremental concept of innovation}

In addition to the technological vs. social dichotomy, two other dichotomies concerning innovation deserve attention for this study. The relationship between radical innovation and incremental innovation, two characteristics that measure its intensity (Ali, 1994; Nakata \& Weidner, 2012). Radical innovation is a product, process or organization that has unprecedented performance characteristics or characteristics that are already known, which promote significant improvements in performance or cost (Lee \& Na, 1994). Radical innovations transform the relationship between consumers and organizations, restructure economic aspects of the market, destabilize existing markets and give rise to completely new product categories. Radical innovation approaches the concept of creative destruction presented by Schumpeter (1984). However, despite being more valued and causing greater impact, only $6-10 \%$ of innovations are radical (Burns \& Stalker, 2000).

The concept of incremental innovation is associated with the concept of continuity, in other words, incremental innovation may occur gradually and periodically, with a longterm goal (Ali, 1994). Incremental innovation may occur after a radical innovation. While radical innovation occurs and creatively destroys a product, process, organization or market, incremental innovation gives continuity to the concept initially introduced by the radical innovation, and therefore, incremental innovation occurs more frequently and with less impact than radical innovation. The innovations positioned to the low-income audience are eminently incremental (Varadarajan, 2009). Thus, it can be said that the intensity of innovation is arranged in a continuous sequence, where the extremes are incremental innovation and radical innovation (Ali, 1994; Antioco \& Kleijnen, 2010; Burns \& Stalker, 2000).

The last dichotomy refers to the adoption of innovation, which is also in a continuous 
sequence between early adopters and late adopters. Early adopters are those who are attentive to the market launches and are the first to buy a new product (Antioco \& Kleijnen, 2010; Nakata \& Weidner, 2011). On the other hand, late adopters are those who are more cautious and prefer to watch the operation of innovation, its characteristics, advantages and disadvantages, to then buy the new product or service, which after a certain period, have lower prices (Antioco \& Kleijnen, 2010; Damanpour \& Schneider, 2006). Therefore, the low-income consumer is a late adopter of innovations.

We know that many radical innovations guided by concepts of disruptive innovation (Christensen, 1997, 2001, 2013) and reverse innovation (Govindarajan \& Ramamurti, 2011; Govindarajan \& Trimble, 2013; Immelt, Govindarajan, \& Trimble, 2009) are positioned specifically for low-income consumers. We also know that there are low-income consumers who are early adopters. This shows how the subject should receive more attention by companies and researchers in recent years. Our point is that incremental innovations are also innovations that effectively cause positive impacts in the lives of low-income consumers. Furthermore, both in the segment of high income and of low-income the curve of innovation adoption (Rogers, 2003) shows early adopters and late adopters; considering the constraints of low-income consumers, theoretically they tend to be late (Nakata \& Weidner, 2011; Varadarajan, 2009; Viswanathan \& Sridharan, 2012).

\section{Low-Income market in Brazil}

In Brazil, the inclusion of the poor in the consumer market was intensified (Parente, Limeira, \& Barki, 2008). Even in an unstable post-crisis world stage, the Brazilian market has maintained high and rising consumption rate among the low-income population (Nogami, Vieira, \& Medeiros, 2012). With the stabilization of economic situation after the implementation of the Real Plan, and with more than a decade of income distribution incentives based on government income transfer programs, purchasing products previously inaccessible became part of the shopping planning of Brazilian families with low income. This phenomenon has drawn the attention of large corporations in the market, and has been the subject of academic research (Viswanathan \& Rosa, 2010).

A study by international consultancy McKinsey predicts that by 2025 , consumption in emerging markets will reach US\$ 3 trillion accounting for half of the total consumption in the world (Ernst, Kahle, Dubiel, Prabhu, \& Subramaniam, 2014). Currently, only $17 \%$ of total revenues of leading companies in western markets derive from emerging markets, although emerging markets represent $36 \%$ of the global GDP (Atsmon, Child, Dobbs, \& Narasimhan, 2012). Therefore, developing economies offer enormous potential for rich and poor countries companies, for both innovations will be necessary for these companies to take advantage of untapped opportunities.

In global terms, Asia (including the Middle East) has the highest concentration of BOP in the world in relation to population and income, accounting for $83 \%$ of the 2.8 billion inhabitants of the region, with a total income of US\$ 3.47 trillion. In terms of population, Africa is the second largest market, made up of 486 million people, although purchasing power is smaller, equivalent to US\$ 429 billion. In Latin America, the market reaches US\$ 509 billion and includes 360 million people. Both in Brazil and Mexico, the BOP accounts for $75 \%$ of the population. Finally, in Eastern Europe, there are 254 million people representing $64 \%$ of the market population with the purchasing power of US\$ 458 billion (Bowman \& Crews, 2012).

Specifically in Brazil, according to Data Popular Report, if the Brazilian class C represented a country, it would be among the 20 largest world consumer markets, with a population of 108 million people who spent $\mathrm{R} \$ 530$ billion in 2013 (Meirelles \& Athayde, 2014). The same survey also showed that the segment bought 3.6 million 
cars and spent $\mathrm{R} \$ 317$ million with cosmetics in 2013. For 2014 the forecast of travel expenses is $\mathrm{R} \$ 8.5$ million within Brazil and $\mathrm{R} \$ 3.2$ million outside the country, and 6.7 million televisions, 4.5 million tablets and 3.9 million smartphones will also be purchased (Meirelles \& Athayde, 2014).

To develop the market in the BOP is a way to reduce the economic problems in developing countries (Zhou, Tong, \& Li, 2011). Organizations that enter this segment, not only to sell, but also to promote business and really understand low-income consumers, can meet this pent-up demand and contribute to the improvement of their lives helping to reduce constraints in their lifestyle. Based on this argument, developing countries like Brazil are the ideal target markets for the development of innovations (Zhou et al., 2011). In other words, there is a relationship between innovation and the low-income market. However, considering all the constraints so far identified, to claim that it is possible to find innovation in the low-income segment does not seem to be easily accepted.

Even with a recent period of political and economic recession (2014-2017), low-income consumers who entered the technological and innovation consumer market, to which they did not previously belong, are now regarded as market share and no longer as "potential" market share. This scenario of recession also influences the adoption of innovation in the process of choosing and making shop decisions. The low-income consumer tends to be more vulnerable to these kinds of crisis.

\section{Method}

To conduct the study, we adopted a mixed methods profile (Brannen, 2005; Creswell, 2013). Thus, the collection, analysis and interpretation of data occurred in 4 steps. Initially, a Delphi survey with Brazilian expert Professors in the field of Marketing and Innovation was conducted. We got in touch via email with all the professors of Marketing and Innovation in
Brazil. The Professors surveyed had necessarily to be professors of post-graduate courses approved by CAPES (regulator of post-graduate courses in Brazil). In the first round, 382 questionnaires were sent via e-mail, out of which 126 were considered valid. In the second round, 50 responses returned out of the 126 questionnaires sent. The first round was characterized as quantitative, with 9 items measured by a 7 -point scale, while the second round was qualitative, where the result of the first round was handed back, the author analyzed this result and the qualitative analysis was requested from these participants. Based on the results of the first round, a question was prepared to gather more information in the second round with one open question. The Delphi survey was guided by Belk (2006) orientations.

The second study consisted of 13 indepth interviews with 4 owners of technical support centers and 8 home appliance retail store managers. An interview was conducted with a former executive of a large factory that operates globally in the home appliances sector (Whirlpool). According to him, the interviews held with technical assistance centers would be most useful for the study, since these professionals work within the homes of consumers and have very accurate information regarding the consumption and especially the use of home appliances. The technical assistance centers interviewed are authorized representatives of major industries in the sector in their respective cities: Mabe Group (representing Continental, Dako, Bosh, General Electric and Mabe), Whirlpool (representing Brastemp and Consul), Electrolux and LG. We tried to contact the managers and directors of these large companies in the home appliances industry tirelessly for over a month, but we did not get a good reception for interviews. So our alternative were the technical assistance centers legally representing the manufactures and having expert knowledge of the products features, in addition to having very close knowledge of the consumers by providing services directly at their homes. In this case, four interviews were conducted. To 
complete this step, we also interviewed eight managers of retail stores. Among these stores, some are nationwide (Ponto Frio, Magazine Luiza, Havan, Colombo) and others serve the regional market (Lojas MM, BJ-Santos, Lojas Mânica and Móveis São Carlos). The in-depth interviews were guided by Belk (2006), Bauer and Gaskel (2008) orientations.

The third study was characterized by the focus group interview. Two interviews were conducted, with 6 and 5 participants, respectively. The profile of the respondents consisted of women/housewives because they are the ones who make the decisions in low-income families, especially regarding household and home appliances (Azevedo \& Mardegan, 2009). The convenience sampling was conducted concerning the accessibility to perform the focus group, criteria of income, and who make the decisions. All of them were employees of the university of a Brazilian higher education institution in the south region, residing in several different neighborhoods. Both the focus group and the in-depth interviews (study 2) had their content analyzed by a qualitative software analysis, since all interviews were duly transcribed (Bardin, 1977; Bauer, 2000; Bazeley, 2011). The focus group interviews followed the guidance of Krueger (2009) and Morgan (1998) orientations. This step, in addition to consisting of qualitative research on the purchasing decisions of lowincome families, also worked as a guide for designing the questionnaire for the next step.

The fourth study consisted of a survey conducted in six convergence points of the city surveyed. Those points were chosen according to the income of the districts as well as the flow of people and trade in each region. Some street commercial centers were prioritized since there is a higher circulation of people and a higher number of retailers offering home appliances. We applied 400 questionnaires, 390 of which were deemed as valid. By conducting research with four different agents in the market, it was possible to understand more fully how innovation was built in the lowincome market. Table 1 summarizes how data was collected in each study:

Table 1

\section{Summary table of data collection}

\begin{tabular}{|c|c|c|c|c|}
\hline \multirow{2}{*}{ Study 1} & $\begin{array}{c}\text { Delphi survey round } 1 \\
\text { (quantitative) }\end{array}$ & 382 questionnaires sent & \multicolumn{2}{|c|}{126 valid questionnaires } \\
\hline & $\begin{array}{c}\text { Delphi Survey round } 2 \\
\text { (qualitative) }\end{array}$ & 126 questionnaires sent & \multicolumn{2}{|c|}{$\begin{array}{l}50 \text { valid questionnaires } \\
\text { (11 pages of responses) }\end{array}$} \\
\hline \multirow{2}{*}{ Study 2} & $\begin{array}{l}\text { Interview with } \\
\text { Manufacturers }\end{array}$ & 5 interviews & $\begin{array}{l}240 \text { minutes of } \\
\text { recording }\end{array}$ & $\begin{array}{l}57 \text { pages of } \\
\text { transcription }\end{array}$ \\
\hline & Interview with Retailers & 8 interviews & $\begin{array}{l}270 \text { minutes of } \\
\text { recording }\end{array}$ & $\begin{array}{l}75 \text { pages of } \\
\text { transcription }\end{array}$ \\
\hline Study 3 & Focus group interview & $\begin{array}{c}2 \text { interview groups } \\
\text { (6 and } 5 \text { participants) }\end{array}$ & $\begin{array}{l}130 \text { minutes of } \\
\text { recording }\end{array}$ & $\begin{array}{l}67 \text { pages of } \\
\text { transcription }\end{array}$ \\
\hline Study 4 & Survey & 400 questionnaires & \multicolumn{2}{|c|}{390 valid questionnaires } \\
\hline
\end{tabular}

The phenomenological and methodological positioning often limits the wealth of data that can be collected in a study. Our methodological approach does not classify as positivist or as interpretivist, we seek the complementarity of these perspectives to study a phenomenon
(Creswell, 2013). Therefore, we have adopted a multi-method research, involving different techniques of collecting and analyzing data, performed with different market players (Creswell \& Clark, 2011; Tashakkori \& Teddlie, 2010). The steps of data collection are interconnected. 
First, we studied the concept of innovation with professors who teach about marketing and innovation in Brazil, to understand how this concept is built academically. Second, we studied the concepts utilized by the industry and the retail. Third, we studied the concept of innovation for the users of products, consumers. Fourth, after comprehending the concept of innovation, we conducted a survey to understand its adoption in the low-income market.

Before presenting the results of each study, it is important to establish two criteria. First, characterize the target audience of the study. Given the magnitude of the low-income, the bottom of the pyramid, base of the pyramid and middle class, confused definitions of the consumers in these types of research is common. In this paper, the factor to determine the audience to be surveyed was the monthly household income of up to US\$ $1,300.00$. In addition, the products selected for these studies were refrigerators, washing machines, stoves and microwaves. These products are considered as essential home appliances, being present in the surveys conducted by the Brazilian Institute of Geography and Statistics (IBGE), the National Household Sample Survey (PNAD - Pesquisa
Nacional por Amostra de Domicilios) and the Consumer Expenditure Survey (POF - Pesquisa de Orçamentos Familiares). These products were also chosen for having more than 10 different brands in the market, because of the more competitive the market, the greater the likelihood for developing innovations (Levitt, 1983). Thus, these are products in the basket of products for low-income consumers and having innovations, suitable for the purpose of this research.

\section{Results}

\section{I Study 1 - Delphi Survey}

To obtain a larger number of answered and valid questionnaires, this step of the study included only 9 questions, the first three variables involve the behavior of low-income consumers, questions 4, 5 and 6 involve the activities of companies, questions 7 and 8 refer to innovation and question 9 refers to the communication of companies. The questions can be viewed in Appendix A. Questionnaires were sent for all 382 graduate professors associated to CAPES programs in Brazil, which research theme is about Marketing or Innovation.

Table 2

Delphi survey mean, standard deviation and Pearson's correlations

\begin{tabular}{l|ccccccccccc}
\hline & $\bar{x}$ & $s$ & 1 & 2 & 3 & 4 & 5 & 6 & 7 & 8 & 9 \\
\hline V1.Interest in buying & 5.406 & 1.563 & 1.000 & & & & & & \\
V2.Actively Buy & 4.063 & 1.710 & $.595^{*}$ & 1.000 & & & & & \\
V3.Financial Availability & 3.047 & 1.413 & $.303^{*}$ & $.468^{*}$ & 1.000 & & & & \\
V4.Interest in offering & 3.938 & 1.839 & $.379^{*}$ & $.442^{*}$ & $.413^{*}$ & 1.000 & & & & \\
V5.Offer & 3.180 & 1.609 & $.278^{*}$ & $.482^{*}$ & $.464^{*}$ & $.690^{*}$ & 1.000 & & & \\
V6.Prepared to offer & 3.656 & 1.638 & .108 & $.238^{*}$ & $.327^{*}$ & $.411^{*}$ & $.507^{*}$ & 1.000 & & \\
V7.Not Innovations & 2.866 & 1.480 & .073 & .154 & .004 & .068 & .148 & .111 & 1.000 & \\
V8.Innovations & 2.953 & 1.562 & .115 & .163 & .162 & $.229^{*}$ & $.282^{*}$ & $.375^{*}$ & $.546^{*}$ & 1.000 \\
V9.Communication & 3.961 & 1.704 & $.255^{*}$ & $.341^{*}$ & .082 & $.391^{*}$ & $.313^{*}$ & $.379^{*}$ & $.297^{*}$ & $.272^{*}$ & 1.000 \\
\hline
\end{tabular}

Note. Data from Round 1 of the Delphi survey. (a) ${ }^{*} \mathrm{p}<.01$ (significance); (b) $\mathrm{n}=126$; (c) 7-point scale

The main highlights of the results of the first round can be viewed in Table 2 , in the questions related to innovation, which indicate the lowest means. The means of V8 and V7 
are very close, 2.953 and 2.866 respectively, in addition to being the lowest, as well as the correlation between V8 and V7, which have the $3^{\text {rd }}$ highest score among the correlations (0.546). Thus, it is possible to conclude that according to the respondents (professors, researchers and consultants), innovations in home appliances for low-income consumers are not effective innovations, but rather adaptations. In other words, according to these professionals, who are responsible for educating managers for the labor market, the innovations developed for the lowincome consumer are incremental innovations, that is, with adjustments and small increments (Prahalad, 2012; Varadarajan, 2009), rather than radical, which destabilize markets (Lee \& $\mathrm{Na}, 1994)$.

Therefore, according to the results presented in the first round, the question (open) for the second round of the Delphi survey was sent to the respondents of the first round. The second round was about the following question: "The variable 7 indicated the second lowest mean and variable 8 indicated the lowest mean, so the professor-respondents did not consider the existence of effective innovations in home appliances for low-income consumers. Based on this result from the first round with Marketing and Innovation researchers, in their opinion, why there are no effective innovations in home appliances for the low-income segment?"

The second stage of the research, which presents qualitative data, contribute more to the beginning of the presentation of the results, as it indicates how the concept of innovation is practiced in the market, from the perspective of the Professors surveyed. At this stage, 50 responses were received. Reports of people assuming they had no sufficient arguments to answer the question of the second round were frequent, considering that, in addition to the fact that they did not directly study the subject regarding innovation with low income, the Professors had scant knowledge of studies linking these two concepts. These reports confirm the lack of research linking innovation and low income.

By categorizing the responses, the two main reasons why the Professors surveyed did not consider that there are effective innovations in home appliances for low-income consumers are based on price. These responses are summarized into: (a) products that have innovation are expensive and are not affordable to low-income consumers, and therefore companies practice the skimming strategy for products that feature innovations, raising their initial price, making it impossible for this product to match the budget of low-income families; and (b) innovation in products targeted for this audience are incremental innovations, with adaptations that do not require large investments, therefore, innovations in products for low-income consumers are not considered as effective innovations, but rather as adaptations. The two excerpts below are answers that represent the two categories found at this stage, respectively:

Whenever innovative products are launched, the pricing policy adopted is "skimming", that is, a higher price to offset the expenditure on R\&D. Prices become more affordable once this segment is saturated or new products are launched by competition and the innovations are no longer innovative. (Professor 1)

To meet the peculiarities of the aforesaid segment, two situations occur simultaneously: the launch of innovations that are new for the company, but not new in the market; and the adequacy of the innovation launched by another company, usually with small adjustments in the projects (materials, processes, finishing), which are not always perceived to be of value to the intended class. (Professor 14)

According to Varadarajan (2009), technology coupled with low price is an assumption needed for large companies who wish to sell to low-income consumers. Due 
adaptations should be performed in the product, production process, distribution, communication and in the management model of the companies in order to reach this audience (Prahallad, 2012; Varadarajan, 2009). Incremental innovations are appropriate for the low-income market, as they appear with adaptations, enhancements, improvements, expansions or reductions incorporating new features that provide additional benefits (Varadarajan, 2009; Viswanathan \& Sridharan, 2012).

The process of innovation requires high investments in $\mathrm{R} \& \mathrm{D}$, so companies that invest in innovation need to recover the investment by practicing the skimming strategy. However, competitors of lower relevance, which do not conduct research, copy the technologies of companies that invest in research and reintroduce them in the market in the form of similar products. This concept, which can be found in the low-income market, is also presented by Levitt (1983), and is called innovative imitation.

Specifically, regarding the home appliances sector, we also found affirmations that indicate that this market is already mature with regard to technology, and therefore, in general, there are no innovations in the market, only reintroductions of technologies that are already known, that is, incremental for everyone. In this same line of thought, a respondent points out that: “[...] many companies just put 'makeup' on the product, changing superfluous features such as color, furnishings (frills) and things like that, seeking to differentiate their product through peripheral rather than core attributes." Along the same line, it was also pointed out that the technology in the home appliances segment is mature and therefore the innovations tend to be slower than in most dynamic segments, such as the segment for electronic components and computing.

\subsection{Study 2 - In-depth interview with and retailers}

The empirical evidence found in the interviews are in line with the results of the
Delphi survey, that is, the concept of innovation in the low-income market is neither an effective innovation nor a radical innovation, they are increments of something that already exists. These increments derive from radical innovations developed for high-income consumers. The innovative attributes of the home appliances mentioned are colors, size, design, and model. In other words, these are accessories in general, which do not effectively change the operation of the product.

The main innovative characteristics of the refrigerators listed by the industry professionals and retailers refer to their internal capacity, energy saving properties and frost-free technology. None of these attributes is a radical innovation. On the other hand, in the case of refrigerators, the frostfree technology was significantly emphasized as being much more convenient for housewives to store frozen food.

Regarding the washing machines, the attributes mentioned are: change from the mechanical to the electrical system, the economy of water, multifunctionality and capacity. Similarly, regarding refrigerators, the innovative attributes are not radical, as proposed by technological determinism. They are just adjustments incorporated to provide the consumer with features that help in their everyday lives. In other words, both the frost-free technology of refrigerators and the multifunctionality of washing machines are not radical innovations, but they allow social changes in the families of lowincome consumers, as stated by the respondents:

If we take this frost-free refrigerator as an example, we are eliminating an activity that a housewife would have to do: defrosting. Cleaning this refrigerator, drying it, checking it every day, preventing the loss of products for not being cooled, all these have been making the consumer's life more practical.

(Manufacturer 1)

Regarding washing machines, there has been a growing demand for washers and 
dryers, that is, products that have multiple functions and take up less space, which ends up being cheaper than buying a washer and a dryer separately; so, products that are multifunctional [...]. Think of the time a housewife, who did not have a washing machine in the past, would spend taking clothes, sorting them, putting them on the washtub, rubbing, spin drying, and today, she just takes them, puts them into the washing machine, closes it, presses a little button, and is free to do other things.

(Retailer 6)

With respect to stoves, the innovative attributes mentioned by the respondents include self-cleaning, number of burners and safety. Concern about the time needed to clean the stove after use becomes a determining factor for purchase. The arrangement of the parts and the ease of handling to remove and re-assemble make a stove user friendly, or otherwise, easy to clean. The oven that is self-cleaning is noteworthy, that is the oven with inner coating made of a type of porcelain that does not accumulate grease, thus not requiring the compartment to be cleaned as often and with as much effort as before. On the other hand, the safety valve is a requirement of National Institute of Metrology, Quality and Technology (INMETRO - Instituto Nacional de Metrologia, Qualidade e Tecnologia), and interrupts the gas supply in case of leaks.

Finally, the microwave was the product listed as having the lowest number of innovations. The respondents' answers referred to convenience and some simple changes in design. There were cases where the respondents pointed out the lack of innovation in the microwave. According to the owner of a technical assistance center "there isn't much to say about a microwave, it is basically the same product, there is no innovation."

It is only possible to identify that the innovative features mentioned have a character of adaptation and reduction of attributes, a downsizing phenomenon that is conducted to serve low-income consumers. This phenomenon does not necessarily mean lower quality products, since low-income consumers, despite strongly approving the price, are also concerned about the product quality, converging with the results of the survey by Barki and Parente (2010) and Parente, Miotto, and Barki (2007). However, there is a clear reduction of attributes in the products developed for this market, as pointed out by a technical assistance center:

The company developed several products that are cheaper, with cheaper raw materials, aiming to provide an option for these consumers, so instead of reducing the quality it reduced the design, removed an extra accessory, as with most stoves, the grill, they no longer have it because they are no longer necessary, because they are in this area, for example, in this area they do not like ovens with a grill because it makes them more expensive. (Technical Assistance 4)

For low-income consumers, we do not have innovative features like those we provide for high-income consumers, but we have intermediate products that are not bad. We have, for example, a "top" product that is expensive, but we also have good products with affordable prices. The product is not bad. In this line, something interesting happens. Even the simplest products offer you varied and different attributes, but they consist of adaptations, with some reductions, of course. (Retailer 1)

The results of this stage of the study support the results found in the Delphi stage. Similar to Professors of Marketing \& Innovation in Brazil, the retailers and manufacturers interviewed did not claim that the innovations effectively developed in home appliances are targeted to low-income consumers. What is called innovation for low-income consumers are actually adaptations and adjustments that are commonly characterized by the reduction of attributes, as indicated by the results of Prahalad's study (2012). 
This phenomenon of downsizing aims to offer a product that has quality, but at a low price, to reach the base of the pyramid (Prahalad \& Hammond, 2002; Prahalad \& Hart, 2002). However, according to the perception of low-income consumers, home appliances are considered innovative, since they were not aware of this technology before, they consider those adjustments and adaptations as innovations, confirming the literature cited in the theoretical framework (Prajogo \& Ahmed, 2006; Rogers, 2003).

In addition to the tangible characteristics, or those that follow a technological perspective, it was also possible to find socially constructed attributes on the innovations of the products surveyed. When manufacturers and retailers point out that housewives can better leverage their time to give more attention to the family and their personal interests, social and cultural issues are involved. These findings can also be evidenced in the focus group interviews, which will be presented in the study 3 below.

\subsection{Study 3 - Focus group}

The purpose of the focus group is not to make structured and directed questions. Idealistically, interviewees should feel at ease to interact among themselves and express their opinions about the topic covered. It is worth noting that the focus group is not meant to be a one-sided conversation. The ideal is that interviewees interact with each other, sharing meanings, opinions, experiences and anything else they consider noteworthy (Morgan, 1998). The participants influence each other by their answers to the ideas and topics broached during the discussion. Thus, in the focus group it is possible to extract information from the participants that cannot be extracted in individual interviews. As a rule, the group must have homogeneous characteristics and not have close contact with the moderator, such being friends, relatives and coworkers. For these interviews, we used two moderators in each focus group.
If for technological determinism, innovation must be characterized by a product/ process/formula/technology that was never seen before, for social constructionism, what matters is the impact of the innovation for certain people, even though incremental. The findings of the research are in line with this perspective. Although they are not strictly considered as innovative, the home appliances positioned to low-income consumers directly impact the day-to-day of these consumers.

This impact was perceived essentially in two categories of responses. The first refers to convenience. In addition to making household chores easier, faster and convenient, these products save housewives' time to perform other activities or to rest. Consequently, the second category refers to the improvement of the quality of life of low-income families. First, we will present the excerpts from transcripts of the focus groups regarding the convenience and time saving, then, regarding the improvement of the quality of life.

Moderator 1: Are you already planning to buy this frost-free refrigerator?

Interviewee 3: Yes, I want the one you don't need to defrost.

Interviewee 4: Preferably the one you don't need to clean in order to save time.

Interviewee 3: Yes, it involves a lot of work, we need more practical things in our dayto-day lives.

Interviewee 8: Today, everything is such a rush, we need to work, study, and my daughter is not at school yet, so it is complicated because I have to multitask everything.

Moderator 2: So, does it make your life easier?

Interviewee 9: It does a lot, life gets a little easier, or better, less complicated. 
Interviewee 10: It does a lot. If it wasn't for these appliances, our daily lives would be much more tiring.

According to the interaction in the focus group, the convenience that home appliances provide in the daily lives of low-income families is well known. Although they are not hightech products, the convenience to do the housework leads to time saving, thus allowing the performance of other activities. Note that the four appliances chosen can be used simultaneously, as pointed out by one of the interviewees "While the clothes are in the washing machine, the oven is baking a cake, the fridge is cooling the dessert, and I'm heating something in the microwave..."

These incremental innovations targeted to the low-income market, even based on adaptations, adjustments and downsizing, impact the daily lives of people. Regarding convenience, the housewives perform: (i) more activities in less time; (ii) more complex activities (heavy) with less effort, and (iii) more than one activity at a time. In short, the main benefit of these innovations is the time saving, which contributes to a greater attention to other activities such as leisure, study, work and entertainment. These other activities are associated with the second category of answers, which is the improvement of the quality of life of low-income people (Nakata \& Weidner, 2012).

Interviewee 3: Look, I have to find something to help me to get some rest, because if I start cooking rice, beans, I'm at the stove for two hours, it's draining.

Moderator 1: And you come home after work feeling tired...

Interviewee 3: And then when will I get some time for myself, if in my house most of the time I am at work? So we have to look for home appliances that will help us out.

Interviewee 1: Yes, we are housewives and we work away from home.
Moderator 1: How is this double shift?

Interviewee 1: It's a rush! It's a rush, I get up in the morning, rush to prepare some food, while I get ready, make breakfast, bathe my child, it is very demanding to do everything at once.

Moderator 1: You do the housework, take care of your husband and children. And how about you, do you take care of yourself? Interviewee 1: I have to find some time for myself.

In this second category, the innovative attributes in home appliances, even if incremental, provide: (i) improved health; (ii) increased selfesteem and even (iii) make dreams come true. A retailer noted that "our products make dreams come true for those consumers who previously had much difficulty with household chores", and a consumer said, "when I bought my washing machine, it was as if a dream had come true, I am a new person with my washing machine."

The excerpt from an interviewee stating that she can have more time with her children and go out on the weekend with her husband demonstrates that her self-esteem increases for being able to interact more with the family socially. These reflections clearly impact people's living standards. This stage of the presentation of results refers to the empirical cases highlighted by Prahalad (2012) in which he reports the impact that portable stoves had on low-income families in India, as they were unable to heat their food. A product with incremental innovative features that improves the quality of life of many people. In other words, these incremental innovations radically affect the lives of low-income families.

\subsection{Overview}

With the three studies conducted by exploratory purpose, the main finding is that the concept of innovation built in the low-income market indicates incremental character, supported 
by adaptations and social issues, as suggested by Prahalad (2012). However, even though these adaptations do not present radical innovations in terms of technology, they have a radical impact in social terms, directly influencing the daily lives of low-income families, as pointed out by Prahalad (2005) and Rogers (2003). The incremental features may also be described as tangible attributes of home appliances, as the social characteristics can be classified as intangible attributes. Thus, Figure 1 below illustrates these two angles of the concept of innovation, technological (tangible) and social (intangible), which was identified according to the investigations of studies 1,2 and 3, with Professors, manufacturers, retailers and consumers.

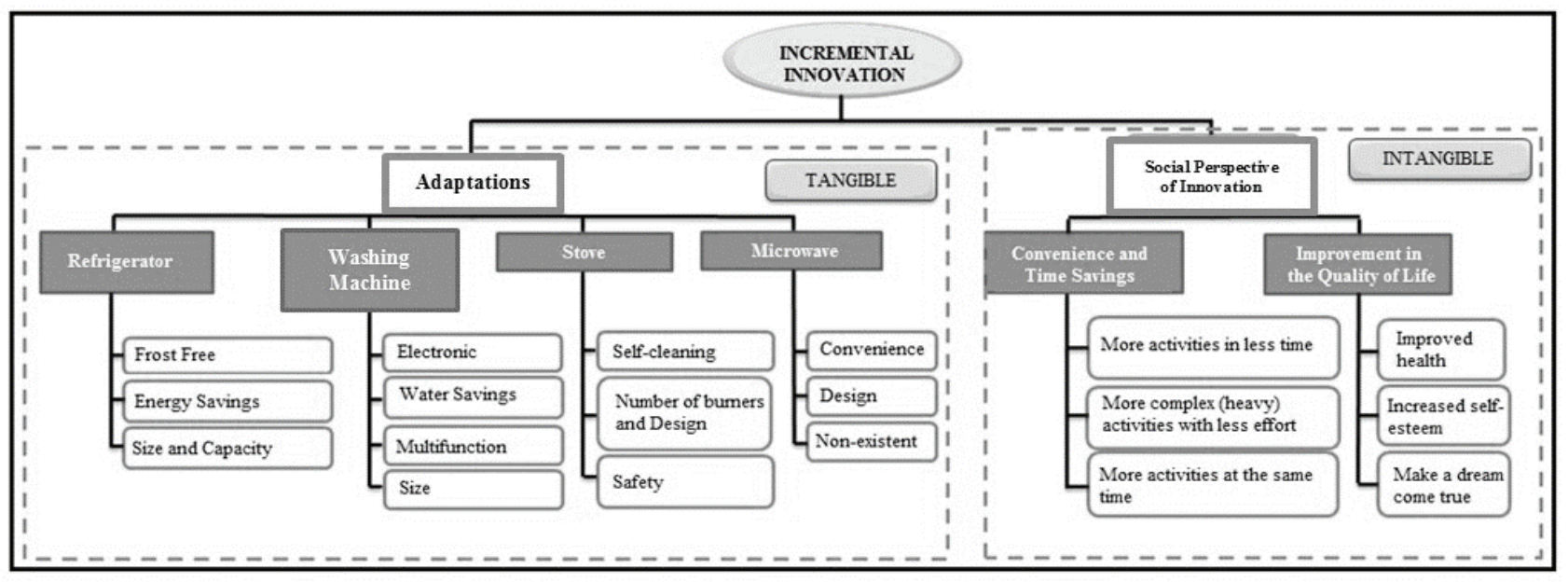

Figure 1. Concept of innovation in the low-income market

The findings suggest that the concept of innovation is built in the low-income market in the form of incremental innovation. This innovation is characterized into tangible and intangible aspects. The tangible aspects are innovative attributes related to adaptations in the home appliances, predominantly characterized by the phenomenon of downsizing. The intangible aspects are of a social character, which involves the day-to-day of low-income consumers, providing convenience, time saving and improved quality of life. Afterw investigating the concept of innovation with the professors of Marketing and Innovation, with professionals of industry and retailers, and consumers, the fourth study seeks to understand the adoption of innovation, being a subsequent study of the first three.

\subsection{Study 4 - Survey}

The last stage of the research consists of a survey conducted at points of convergence and street commercial centers of the city where data collection took place. These places were chosen because there is a high flow of consumers with the income determined by the study. The six points chosen comprised bus station regions, near shopping malls and downtown areas. We administered 400 questionnaires, 390 of which were considered valid. After investigating the concept of innovation, in this stage the characteristics of this concept were analyzed. First related to the intensity, within a continuous sequence between radical and incremental. Then, regarding the adoption, which may be early or late. The questionnaire can be found in Appendix B.

As shown in Table 3, the means of the first three questions are higher than the means of the last three. Given that the first three questions are indicators of incremental innovation in home appliances, and the last three are indicators of radical innovation, it can be concluded that the concept of innovation reproduced by the 
respondents is incremental (Ali, 1994; Nakata \& Weidner, 2012; Varadarajan, 2009). Estimating the average of the means of the first three questions, we reach the value of 3.59 , the same procedure with the last three questions result in a much smaller value, 2.48 . In other words, the perception of innovation in home appliances is of incremental innovation.

Table 3

\section{Mean, standard deviation and Pearson's correlation between the variables of intensity of innovation}

\begin{tabular}{|c|c|c|c|c|c|c|c|c|c|c|c|}
\hline & & & $\bar{x}$ & s & $\alpha$ & 1 & 2 & 3 & 4 & 5 & 6 \\
\hline \multirow{6}{*}{ 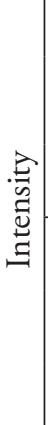 } & \multirow{3}{*}{ 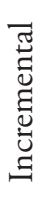 } & 1. Have little technology & 3.13 & 1.49 & & 1 & & & & & \\
\hline & & $\begin{array}{l}\text { 2. There are already more advanced } \\
\text { technologies }\end{array}$ & 4.18 & 1.18 & .359 & $.144^{* *}$ & 1 & & & & \\
\hline & & 3. Innovation is for those who have money & 3.48 & 1.66 & & $.278^{* *}$ & .031 & 1 & & & \\
\hline & \multirow{3}{*}{ 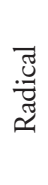 } & 4. More advanced technology & 2.56 & 1.44 & & -.074 & .044 & $-.137^{* *}$ & 1 & & \\
\hline & & 5. Have high technology & 2.44 & 1.43 & .774 & $-.220^{* *}$ & .033 & $-.258^{* *}$ & $.528^{* *}$ & 1 & \\
\hline & & 6. Are novelties with innovation & 2.44 & 1.49 & & $-.202^{* *}$ & .053 & $-.307^{* *}$ & $.391^{* *}$ & $.681^{* *}$ & 1 \\
\hline
\end{tabular}

Note. ${ }^{* *} \mathrm{p}<0.01$ (significance); ${ }^{*} \mathrm{p}<0.05$ (significance)

Not only the means, but the correlation coefficients also indicate this result. The highest correlation coefficients in Table 3 are among the variables 4, 5 and 6 , indicators related to radical innovation, that is, there is a strong correlation between these variables, and these variables have low means compared to the first three. Another index that indicates this consistency is the Cronbach's alpha among the three questions, reaching 0.774 , satisfactory according to Hair, Tatham, Anderson, and Black (2009), that is, there is consistency between these variables. The Cronbach's alpha among the first three questions is not satisfactory, but its means are clearly higher than the means of the last three questions, and there are significant correlations between their variables. Also, the negative correlations may indicate divergent validity between the variables. To reinforce the conclusion, we also conducted a factor analysis between these variables, as shown below.

Table 4

\section{Exploratory factor analysis between the variables of intensity}

\begin{tabular}{|c|c|c|c|}
\hline & & Radical & Incremental \\
\hline \multirow{3}{*}{ 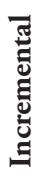 } & 1. Buy low-tech & & .748 \\
\hline & 2. There are already more advanced technologies & & .638 \\
\hline & 3. Innovation is for those who have money & & .549 \\
\hline \multirow{3}{*}{ 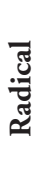 } & 4. The latest in the market & .739 & \\
\hline & 5. Have the latest technology & .870 & \\
\hline & 6. Are the latest novelties with innovation & .821 & \\
\hline
\end{tabular}

Note. a. Extraction Method: Principal Component Analysis; b. Rotation Method: Varimax. 
According to the exploratory factor analysis in Table 4, it is possible to note the grouping of indicators related to the intensity of innovation. It is clear that the loads are grouped into two factors; factor one referring to incremental innovation and factor two, to radical innovation. It is concluded that there are differences between these two concepts, and that according to lowincome consumers, the innovation adopted in home appliances is characterized as incremental, referring to the concept of downsizing mentioned above in the previous steps (study 1, 2 and 3 ), illustrated in Figure 1.

Continuing with the analysis, Table 5 shows the questions related to the adoption of innovation. Observing the means of the questions, it can be seen that the last three means are higher than the first three. The last three are variables that indicate the late adoption of innovation since the first three indicate whether it refers to early adopters of innovation.

Table 5

Mean, standard deviation and Pearson's correlation between the variables of adoption

\begin{tabular}{|c|c|c|c|c|c|c|c|c|c|c|c|}
\hline & & & $\bar{x}$ & $s$ & $\alpha$ & 7 & 8 & 9 & 10 & 11 & 12 \\
\hline \multirow{6}{*}{ 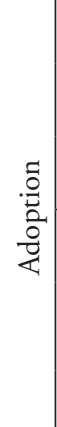 } & \multirow{3}{*}{ 矛 } & 7. One of the first to buy & 2.06 & 1.35 & & 1 & & & & & \\
\hline & & 8. Understands wel 1 the new features & 3.05 & 1.46 & 0.444 & $.120^{*}$ & 1 & & & & \\
\hline & & 9. Buy before others & 1.87 & 1.27 & & $.434^{* *}$ & $.101^{*}$ & 1 & & & \\
\hline & \multirow{3}{*}{ 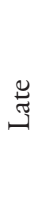 } & 10. One of the last to buy & 3.09 & 1.45 & & -.039 & -.095 & -.052 & 1 & & \\
\hline & & $\begin{array}{l}\text { 11. Difficulty in understanding the } \\
\text { technology }\end{array}$ & 3.19 & 1.49 & 0.545 & -.020 & $-.412^{* *}$ & -.071 & $.196^{* *}$ & 1 & \\
\hline & & 12. Buy after others & 3.36 & 1.45 & & -.073 & $-.162^{* *}$ & $-.175^{* *}$ & $.422^{* *}$ & $.243^{* *}$ & 1 \\
\hline
\end{tabular}

Note. ${ }^{* *} \mathrm{p}<0.01$ (significance); ${ }^{*} \mathrm{p}<0.05$ (significance)

According to Azevedo and Mardegan (2009), the low-income consumer cannot afford to try new purchases, new products and risk the certain for the uncertain. Since the income is limited due to the restrictions of the family budget, buying products that lack stability with regard to quality, usability and functionality is a risk (Hamilton, 2009; Prahalad, 2012). By estimating the means of the questions relating to early adoption, we reach a value of 2.32 . The means of the questions relating to late adoption reaches 3.21. Note also that the coefficients highlighted (shaded) in Table 5, which correspond to the same dimension, are the only ones with positive values, indicating a positive correlation between the variables. On the other hand, the negative values indicate the divergent validity between the variables.
An indicator which is slightly different from the expected is the mean of variable 8 , but it can be explained by the ease of use of the products proposed by the industry. The plug and play concept is usually found in products for lowincome consumers due to the difficulties they may have when handling the products. So, possibly, the respondents did not present answers that match the difficulty in understanding the innovations in products. According to one interviewee "a child knows how to handle it (washing machine), because it has no secret, just press a button," yet according to one of the retailers interviewed "today, all these products are plug and play right, there is no mistake, everyone knows how to use it."

To strengthen the analysis of the consistency of these two dimensions, Table 6 presents the exploratory factor analysis between 
the variables. In the first factor, there is a clear consistency between the variables related to late adopters, thus confirming the analysis of the correlations. On the other hand, the first three variables related to the early adoption are not grouped in the same factor; question 8 does not fit the other two, possibly because the lowincome consumer has no difficulty in handling home appliances, due to the plug and play feature described above.

Table 6

\section{Exploratory factor analysis between the variables of adoption}

\begin{tabular}{l|lcc}
\hline & Late & Early \\
\hline 7. One of the first to buy & & .848 \\
8. Understands well the new features & .584 & \\
9. Buy before others & & .834 \\
10. One of the last to buy & .652 & .714 \\
11. Difficulty in understanding the technology & .696 \\
12. Buy after others
\end{tabular}

Note. a. Extraction Method: Principal Component Analysis; b. Rotation Method: Varimax.

To conclude the presentation of study 4 , Table 7 shows the correlation between the means of the dimensions intensity and adoption: (i) incremental innovation; (ii) radical innovation; (iii) early adoption, and (iv) late adoption. These new variables were created based on the mean of the questions of each respondent.

\section{Table 7}

\section{Correlation between the means of the dimensions (Intensity x Adoption)}

\begin{tabular}{lcccc}
\hline & Incremental & Radical & Early & Late \\
\hline Incremental & 1 & & & \\
Radical & $-.243^{* *}$ & 1 & & \\
Early & -.085 & $.417^{* *}$ & 1 & \\
Late & $.307^{* *}$ & $-.195^{* *}$ & $-.252^{* *}$ & 1 \\
\hline
\end{tabular}

Note. ${ }^{* *} \mathrm{p}<0.01$ (significance)

Note that only two coefficients have positive values. The first and largest is the correlation between radical innovation and early adopters, that is, consumers who perceive the intensity of the innovation as radical, these people are generally more prone to buy an innovative product early. On the other hand, consumers who perceive innovation as incremental, tend to wait to buy new products. This second segment characterizes the typical behavior of low-income consumers, who reproduce the concept of incremental innovation and wait for others to buy to be sure it will be a good acquisition.

\section{Discussion}

The aim of this paper was to investigate how the low-income market understands and adopts innovations. Consequently, we conducted four different and subsequent studies. After the whole process of data collection and analysis, the result points out the socially constructed characteristics, in addition to technological attributes, for the concept of innovation regarding features. The main contribution of our research is summarized in Figure 1 and relates to the insight that innovation is understood by consumers as being tangible (product characteristics) or intangible (product benefits). On the other 
hand, studies 1, 2 and 3 demonstrated that companies innovation strategies based on this analysis can also be seen through a prism of tangibility, as shown in Figure 1, which is the main theoretical and empirical contribution of the paper. The concept of innovation built in the low-income market is based on the phenomenon of downsizing in a non-radical approach, mainly incremental. That is, the innovations are not radical, but rather adaptations that characterize them as incremental. This phenomenon was identified based on studies 1, 2 and 3 held with Professors, industry executives and retailers and low-income consumers.

The research findings show that the concept of innovation in the low-income market resembles the frugal innovation concept. Frugal innovation refers to building products based on the most important needs, being a recent concept of innovation targeted to meet the needs of the low-income market. Also identified as frugal engineering or constraint-based innovation, this innovation directly targets the needs in the context of the uncertainty of low-income markets (Khanna \& Palepu, 2013). The term means innovations, specifically developed for resourceconstrained people in constraints conditions (Zeschky, Winterhalter, \& Gassmann, 2014).

Frugal innovation focuses on developing appropriate, adaptable, affordable, and accessible services and products for low-income markets, same issues we found in Figure 1 (Basu, Banerjee, \& Sweeny, 2013). In order to solve sustainability challenges in low-income markets, social enterprises adopt frugal innovation and entrepreneurship. They focus on the development of simple and sustainable products, processes, and business models with a low input of resources, low cost, and little environmental intervention (Brem \& Ivens, 2013). In other words, this kind of innovation is driven by the uncertainties of low-income markets (Khanna \& Palepu, 2013).

The tangible attributes are related to the advantages of home appliances. The refrigerator has advantages with the frost-free technology; energy saving; and changes in size and storage capacity. The washing machine is characterized as electronic; water saving; multifunctional; and size related to wash ability. The stove's main attribute is self-cleaning; the provision and number of burners; and the safety of the supply of gas. The microwave, except for the size and design, indicates no innovative features. These incremental attributes in products are crucial to building the concept of innovation and understanding the adoption of innovation (Nakata \& Weidner, 2012). Often incremental innovations have higher effects on market penetration than radical innovations (Rogers, 2003; Varadarajan, 2009)

The intangible attributes are related to the social perspective that innovation can provide to consumers (Prahalad, 2012; Viswanathan \& Sridharan, 2012). These attributes are divided into (i) convenience and time saving and (ii) improvement in the quality of life. Consumers considered innovations to be convenient and time saving because they can perform more activities in less time; more complex and hard activities with less effort; and more activities simultaneously. As for the improvement in the quality of life, we identified deeper benefits: improved health; increased self-esteem; and fulfillment of a dream. More than the innovation of high cost with high technology, the social benefits of improvement of life are the main contributions of innovation for the low-income market (Nogami, Pilli, Mazzon, Vieira, \& Veloso, 2015a).

Finally, with Study 4, it was concluded that low-income consumers perceive innovations in the home appliances market to be incremental, that is, without much technological advancement. When considering the adoption of innovations process, low-income consumers can be classified as late adopters, that is, they prefer to wait for others to buy new products, minimizing their risk (Anderson \& Billou, 2007; Anderson \& Markides, 2007; Prahalad, 2012). 


\section{Final remarks}

As a conclusion, we emphasize a managerial contribution regarding the understanding and use of the concepts pointed out by the companies seeking to serve low-income consumers. Companies should focus on innovations that facilitate the use of products, provide convenience in everyday life, and have a minimum level of satisfactory quality. Since low-income consumer adopts innovations at a later moment, mitigating their fear and insecurity when buying new products is key to attract them before the competitors.

This conclusion shows us that to achieve success in terms of innovation, business and marketing professionals are as or more important than technology and engineering professionals. Understanding socially constructed concepts immersed in specific characteristics of income, culture and lifestyle as well as knowledge constraints, insecurity, uncertainty and weak infrastructure increase the likelihood of diffusion and adoption of innovation in the low-income market.

In terms of theoretical contributions, the present study reveals how the concept of innovation is built in the low-income market. From a perspective constructed collectively with information from different market agents (industry, retail and consumers), research findings become robust to understanding a phenomenon. In other words, different points of view at the marketplace were considered in the construction of innovation concepts in low-income market.

Moreover, in addition to different market agents, different methods of data collection and analysis were also used, further enriching the results. This collective contribution, based theoretically on a literature of social construction, interviewing different market agents and using different methodological approaches, synergistically potentiated the development of this paper.

One limitation of this study consists in presenting four extensive studies into just one article. Seeking to be comprehensive, in view of the complexity of the studies, as well as detailed, given the deepening in the analysis of results, we may have overlooked an aspect or another in the study. The contact with low-income consumers was not easy at first, as the feeling of distrust in studies 3 and 4 were present in a few moments.

In study 1 only Professors of Marketing and Innovation were contacted, the advantage is that they are experts on this topic, a downside is the limited number of respondents, moreover, only 50 Professors participated in both stages of the Delphi survey. On the choice of respondents in study 2, although we are supported by the Azevedo and Mardegan (2009) statement that women are the key decision-makers in lowincome families, knowing the opinion of men/ husbands, sons and daughters, grandfathers and grandparents-in-laws is important too, because usually the family composition in low income is very complex and even confusing.

The city chosen for research has peculiar characteristics, not being a big city, but it is not a small town, representing a potential emerging consumer class that is evidenced in Brazil. Researches in cities with over 1 million people and also in small towns spread across the country are also key to understanding the adoption of innovation in the low-income market. Finally, the results of our studies are industry specific. Nevertheless, the categories are present in the product basket of consumer low-income families, and can effectively contribute to the development and maturation of knowledge in the area.

In addition, Brazilian low-income families have experienced a recent period of quick social and economic growth. This empowerment may have been one of the responsible aspects for the greater adoption of innovations by this public. Currently, Brazil is experiencing an economic crisis that affects all its population. However, economically disadvantaged people suffer more from the effects of the crisis. In this way, investigating the effects of the economic crisis on the adoption of innovation becomes an interesting suggestion for future research. 
Finally, in methodological terms, we encourage the conduct of multi-method research, adopting qualitative and quantitative models as complementary, to refine the analysis of the results of academic and management research. In-depth studies involving the topics of innovation with the low-income market is also a proposal that strengthens both knowledge in Innovation and Marketing, from the $\mathrm{B} 2 \mathrm{~B}$ relationship between the industry and the retail segment to a better understanding of the end consumer behavior.

\section{References}

Ali, A. (1994). Pioneering versus incremental innovation: Review and research propositions. Journal of Product Innovation Management, 11(1), 46-61.

Anderson, J., \& Billou, N. (2007). Serving the world's poor: Innovation at the base of the economic pyramid. Journal of Business Strategy, 28(2), 14-21.

Anderson, J., \& Markides, C. (2007). Strategic Innovation at the Base of the Pyramid. MIT Sloan Management Review, 49(1), 82-89.

Antioco, M., \& Kleijnen, M. (2010). Consumer Adoption of technological innovations: Effects of psychological and functional barriers in a lack of content versus a presence of content situation. European Journal of Marketing, 44(11/12), 17001724.

Atsmon, Y., Child, P., Dobbs, R., \& Narasimhan, L. (2012). Winning the $\$ 30$ trillion decathlon: Going for gold in emerging markets. McKinsey Quarterly, 4, 20-35.

Azevedo, M., \& Mardegan, E. (2009). O consumidor de baixa renda: Entenda a dinâmica de consumo da nova classe média brasileira. Rio de Janeiro: Elsevier.

Bardin, L. (1977). L'analyse de contenu. Paris: Presses Universitaires de France.
Barki, E. \& Parente, J. G. (2010). Consumer behaviour of the base of the pyramid market in Brazil. Greener Management International, 56(1), 11-23.

Basu, R., Banerjee, P., \& Sweeny, E. (2013). Frugal innovation: Core competencies to address global sustainability. Journal of Management for Global Sustainability, 1(2), 63-82.

Bauer, M. (2000). Classical content analysis: A review. In M. Bauer \& G. Gaskell, Qualitative researching with text, image and sound: A practical handbook for social research (pp. 132-152). Thousand Oaks: Sage Publications.

Bauer, M., \& Gaskell, G. (2000). Qualitative researching with text, image and sound: A practical handbook for social research. Thousand Oaks: Sage Publications.

Bazeley, P. (2011). Qualitative data analysis with NVIVO. Thousand Oaks: Sage Publications.

Belk, R. W. (2006). Handbook of qualitative research methods in marketing. Bodmin: Great Britain by MPG Books Ltd.

Bowman, M., \& Crews, C. (2012). Engineering solutions for the base of the pyramid: A report prepared for the Strategic Issues Committee. Massachusetts, USA: ASME, AndSpace Consulting.

Brannen, J. (2005). Mixing methods: The entry of qualitative and quantitative approaches into the research process. International Journal of Social Research Methodology, 8(3), 73-84.

Brem, A., \& Ivens, B. (2013). Do frugal and reverse innovation foster sustainability? Introduction of a conceptual framework. Journal of Technology Management for Growing Economies, 4(2), 31-50.

Brem, A., \& Wolfram, P. (2014). Research and development from the bottom up: Introduction of terminologies for new product development in emerging markets. Journal of Innovation and Entrepreneurship, 3(1), 1-22. 
Burns, T., \& Stalker, G. M. (2000). The management of innovation. New York: Oxford University Press.

Christensen, C. (1997). The innovator's dilemma. Boston: Harvard Business School Press.

Christensen, C. (2001). The past and future of competitive advantage. Sloan Management Review, 42(2), 105-109.

Christensen, C. (2013). The innovators dilemma: When new technologies cause great firms to fail. Boston: Harvard Business Review Press.

Corsi, S., \& Di Minin, A. (2014). Disruptive innovation... in reverse: Adding a geographical dimension to disruptive innovation theory. Creativity and Innovation Management, 23(1), 76-90.

Creswell, J. W. (2013). Research design: Qualitative, quantitative, and mixed methods approaches. Thousand Oaks: Sage Publications.

Creswell, J. W., \& Clark, V. L. P. (2011). Designing and conducting mixed methods research. Thousand Oaks: Sage Publications.

Dagnino, R. (2008). Neutralidade da ciência e determinismo tecnológico: Um debate sobre a tecnociência. Campinas, SP: Ed. Unicamp.

Damanpour, F., \& Schneider, M. (2006). Phases of the adoption of innovation in organizations. British Journal of Managementk 17(3), 215-236.

Ernst, H., Kahle, H. N., Dubiel, A., Prabhu, J., \& Subramaniam, M. (2014). The antecedents and consequences of affordable value innovations for emerging markets. Journal of Product Innovation Management, 32(1), 65-79.

Govindarajan, V., \& Ramamurti, R. (2011). Reverse innovation, emerging markets, and global strategy. Global Strategy Journal, 1(3-4), 191-205.

Govindarajan, V., \& Trimble, C. (2013). Reverse innovation: Create far from home, win everywhere. Boston: Harvard Business Press.
Hair, J. F., Tatham, R. L., Anderson, R. E., \& Black, W. (2009). Multivariate data analysis (7th ed.). Upper Saddle River: Prentice Hall.

Hall, J., Matos, S. V., \& Martin, M. J. (2014). Innovation pathways at the base of the pyramid: Establishing technological legitimacy through social attributes. Technovation, 34(5), 284-294.

Hamilton, K. (2009). Consumer decision making in low-income families: The case of conflict avoidance. Journal of Consumer Behaviour, 8(2), 252-267.

Hang, C-C., Chen, J., \& Subramian, A. M. (2010). Developing disruptive products for emerging economies: Lessons from Asian cases. Research Technology Management, 53(4), 21-26.

Immelt, J. R., Govindarajan, V., \& Trimble, C. (2009). How GE is disrupting itself. Harvard Business Review, 87(10), 56-65.

Khanna, T., \& Palepu, K. (2013). Winning in emerging markets: A road map for strategy and execution. Boston: Harvard Business Press.

Krueger, R. A. (2009). Focus groups: A practical guide for applied research. Thousand Oaks: Sage.

Kuczmarski, T. D. (2003). What is innovation? And why aren't companies doing more of it? Journal of Consumer Marketing, 20(6), 536-541.

Lee, M. \& Na, D. (1994). Determinants of technical success in product development when innovation radicalness is considered. Journal of Product Innovation Management, 11(1), 62-68.

Levitt, T. (1983). The marketing imagination. New York: The Free Press.

London, T. (2016). The base of the pyramid promise: Building businesses with impact and scale. California: Stanford University Press.

Medeiros, J., Vieira, F. G. D., \& Nogami, V. K. C. (2014). A construção do mercado editorial eletrônico no Brasil por meio de práticas de marketing. Revista de Administração Mackenzie, 15(1), 152-173. 
Meirelles, R., \& Athayde, C. (2014). Um pais chamado Favela: A maior pesquisa já feita sobre a favela brasileira. São Paulo: Ed. Gente.

Morgan, D. L. (1998). The focus group guidebook. Thousand Oaks: Sage Publications.

Nakata, C., \& Weidner, K. (2012). Enhancing new product adoption at the base of the pyramid: A contextualized model. Journal of Product Innovation Management, 29(1), 21-32.

Nogami, V. K. C., Pilli, L. E., Mazzon, J. A., Vieira, F. G. D., \& Veloso, A. R. (2015a). Innovation in low-income market: A study based on the symbolic production and cultural reproduction. BASE-Revista de Administração e Contabilidade da Unisinos, 12(4), 331-342.

Nogami, V. K. C., Vieira, F. G. D., \& Medeiros, J. (2012). Reflexões acadêmicas e de mercado para o marketing na base da pirâmide. Revista de Negócios, 17(4), 55-73.

Nogami, V. K. D. C., Vieira, F. G. D., \& Medeiros, J. (2015b). Construção de mercados: Um estudo no mercado de notebooks para baixa renda. Gestão \& Regionalidade, 31(93), 59-75.

Nogami, V. K. D. C., \& Veloso, A. R. (2017). Disruptive innovation in low-income contexts: challenges and state-of-the-art national research in marketing. Revista de Administração e Inovação, 14(2), 162-167.

Parente, J. G, Limeira, T. M., \& Barki, E. (2008). Varejo para a baixa renda. Porto Alegre: Bookman.

Parente, J. G., Miotto, A., \& Barki, E. (2007). Polos comerciais na rua. GVexecutivo, 6(6), 49-54.

Prahalad, C. K. (2005). The fortune at the bottom of the pyramid: Eradicating poverty through profits. Upper Saddle River: Wharton School Publishing.

Prahalad, C. K. (2012). Bottom of the pyramid as a source breakthrough innovation. Journal of Product Innovation Management, 29(1), 6-12.
Prahalad, C. K., \& Hammond, H. (2002). Serving the world's poor profitably. Harvard Business Review, 80(9), 4-11.

Prahalad, C. K., \& Hart, S. (2002). The fortune at the bottom of the pyramid. Strategy and Business, 26(1), 1-22.

Prajogo, D. I., \& Ahmed, P. K. (2006). Relationship between innovation stimulus, innovation capacity and innovation performance. R\&D Management, 36(5), 499-515.

Rogers, E. (2003). Diffusion of innovation (5nd ed.). New York: Free Press.

Schumpeter, J. (1984). Capitalismo, socialismo e democracia. Rio de Janeiro: Zahar Ed.

Tashakkori, A., \& Teddlie, C. (2010). Sage handbook of mixed methods in social $\&$ behavioral research. Thousand Oaks: Sage Publications.

Varadarajan, R. (2009). Fortune at the bottom of the innovation pyramid: The strategic logic of incremental innovations. Business Horizons, 52(1), 21-29.

Viswanathan, M. (2011). Conducting transformative consumer research: Lessons learned in moving from basic research to transformative impact in subsistence marketplaces. In D. G. Mick, S. Pettigrew, C Pechmann, \& J. L. Ozanne (Eds.), Transformative consumer research for personal and collective well-being (pp. 109130). London: Routledge/Taylor \& Francis, Forthcoming.

Viswanathan, M. (2016). Bottom-up enterprise: Insights from subsistence marketplaces [Kindle Edition]. Retrieved from https://www. amazon.com/Bottom-Up-Enterprise-InsightsSubsistence-Marketplaces-ebook

Viswanathan, M., \& Rosa, J. A. (2010). Understanding subsistence marketplaces: Toward sustainable consumption and commerce for a 
better world. Journal of Business Research, 63(6), 535-537.

Viswanathan, M., \& Sridharan, S. (2012). Product development for the bop: Insights on concept and prototype development from university-based student projects in India. Journal of Product Innovation Management, 29(1), 52-69.

Viswanathan, M., Sridharan, S., Gau, R., \& Ritchie, R. (2009). Designing marketplace literacy education in resource-constrained contexts: Implications for public policy and marketing. Journal of Public Policy and Marketing, 28(1), 85-94.
Zeschky, M. B., Winterhalter, S., \& Gassmann, O. (2014). From cost to frugal and reverse innovation: Mapping the field and implications for global competitiveness. Research-Technology Management, 57(4), 20-27.

Zhou, J., Tong, Y., \& Li, J. (2011). Disruptive innovation in China's BoP market. Proceedings of the Technology Management in the Energy Smart World (PICMET), Portland, Oregon, USA. p. 1-7.

\section{Note}

1 A preliminary version of this article was presented on European Marketing Academy (EMAC) 2014

\section{Supporting agencies:}

Coordenação de Aperfeiçoamento de Pessoal de Nível Superior - CAPES.

\section{About the authors:}

Vitor Koki da Costa Nogami, PhD in Business, School of Economics, Business and Accounting of University of Sao Paulo, Brazil. E-mail: vitornogami@gmail.com.

\section{ORCID}

(iD) 0000-0001-5185-731X

Francisco Giovanni David Vieira, PhD in Social Science, Pontifical Catholic University of Sao Paulo,

Brazil. E-mail: fgdvieira@uem.br.

ORCID

(iD) 0000-0002-6204-0855

Andres Rodriguez Veloso, PhD in Business, School of Economics, Business and Accounting of University of Sao Paulo, Brazil. E-mail: veloso@usp.br.

ORCID

(D) 0000-0003-3037-6773

\section{Contribution of each author:}

\begin{tabular}{lccc}
\hline Contribution & $\begin{array}{c}\text { Vitor Koki da Costa } \\
\text { Nogami }\end{array}$ & $\begin{array}{c}\text { Francisco Giovanni } \\
\text { David Vieira }\end{array}$ & $\begin{array}{c}\text { Andres Rodriguez } \\
\text { Veloso }\end{array}$ \\
\hline $\begin{array}{l}\text { 1. Definition of research problem } \\
\text { 2. Development of hypotheses or research questions }\end{array}$ & Not applicable & Not applicable & Not applicable \\
(empirical studies) & Not applicable & Not applicable & Not applicable \\
3. Development of theoretical propositions (theoretical Work) & $\sqrt{ }$ & $\sqrt{ }$ \\
4. Theoretical foundation/ Literature review & $\sqrt{ }$ & $\sqrt{ }$ \\
5. Definition of methodological procedures & $\sqrt{ }$ & $\sqrt{ }$ \\
6. Data collection & $\sqrt{ }$ & $\sqrt{ }$ \\
7. Statistical analysis & $\sqrt{ }$ \\
8. Analysis and interpretation of data & $\sqrt{ }$ \\
9. Critical revision of the manuscript & $\sqrt{ }$ & $\sqrt{ }$ \\
10. Manuscript Writing & $\sqrt{ }$ & $\sqrt{ }$ \\
11. Translation & & & $\sqrt{ }$ \\
\hline
\end{tabular}

